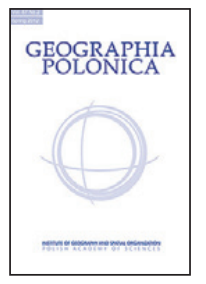

\title{
MOISTURE AND CIRCULATION CONDITIONS DURING HEAVY PRECIPITATION EVENTS IN ŁÓDŹ
}

\section{Piotr Piotrowski}

Department of Meteorology and Climatology, Faculty of Geographical Sciences University of Łódź

Narutowicza 88, 90-139 Łódź: Poland

e-mail: janos33@wp.pl

\begin{abstract}
A detailed analysis was performed of precipitation data from the years 2011-2013 collected from 17 stations in the city of Łódź over six days with the highest six-hour precipitation periods. Each day was analyzed in respect of the synoptic conditions affecting the weather, with particular emphasis placed on moisture conditions. The highest precipitation was recorded during the May to August period. The convergence of thermally contrasting air masses and significant amounts of water vapor transported to the area of Central Europe were the main cause of extreme precipitation in the area of Łódź. During the advection of warm air masses, the significant amount of water vapor in the air originated not only from the warm sea basins, but also from evapotranspiration during the air masses travelling over hot land areas. A high content of precipitable water during heavy precipitation events was reported in the area of Poland and its neighborhood.
\end{abstract}

\section{Key words}

extreme precipitation $\bullet$ water vapor flux $\bullet$ precipitable water $\bullet$ atmospheric circulation

\section{Introduction}

High precipitation in cities may have both negative and positive effects. From the point of view of urban hydrology, both short-term intense rainfall, mostly with a small territorial range, and long-lasting rainfall of less intensity but spanning a larger area, may result in damaging industrial infrastructure as a consequence of land flooding (Kotowski et al. 2010a). A significant positive effect of atmospheric precipitation is the removal of air pollutants by rain. The spatial variation in precipitation intensity in urban areas can be considerable even in a relatively small area. In the area of Wrocław, differences in the intensity of precipitation reaching 15-20\% were observed (Kotowski et al. 2010b). Even small spatial changes in anomalous precipitation may be decisive for the occurrence of local flooding.

The factors affecting the distribution and amount of rainfall in the city can 
be investigated at a local or global scale. The most common factors considered at a local scale are: urban heat island (UHI), roughness of urban surface, aerosols and water vapor emissions. Numerous scientific publications have been dedicated to the relationships between urban development, human activities and the amount of precipitation.

Dubaniewicz (1974) attempted to assess the impact of the city and terrain on the spatial distribution of precipitation in the area of Łódź and its surroundings (in a radius of up to approx. $100 \mathrm{~km}$ ). The study was in fact a case study and was based on five days of precipitation under different directions of advection. The results of the analysis showed that the impact intensity of local factors on the distribution of precipitation differed depending on the direction of advection. In the study of Dubaniewicz (1974), information can be found about higher precipitation totals in the eastern part of Łódź. The author assumed that the area of the city and its land topography could modify the spatial distribution of precipitation occurrence. The impact of local factors on precipitation in the area of Łódź is mentioned in a study by Bartnik and Marcinkowski (2015). The authors have listed a number of factors which can affect the spatial distribution of rainfall in the city: land orography, urban heat island, surface roughness, forced convection. The authors of the study have also paid attention to a global factor by allowing for the direction of the inflow of moist air masses. The degree of impact of individual local factors on precipitation and its spatial distribution remains in the realm of the authors' presumptions and is not supported by any solid arguments.

One of the earliest studies in this field was conducted in the 1970s by Ackerman et al. (1978). It shows that the mixing height is higher over the city than over rural areas and that heat and moisture are transported to higher layers of troposphere. Such conditions may be conducive to nocturnal convective storms. Dixon and Mote (2003) suggest that precipitation may be initiated by the urban heat island $(\mathrm{UHI})$. The urban heat island can contribute to a near-surface convergence of air currents and consequently to updrafts on the leeward or windward side of a city (Han et al. 2014). Authors suggest that precipitation is likely to further increase under higher aerosol concentrations if the air moisture is high and deep and strong convection occurs. The same authors confirm that larger surface roughness does not appear to play a major role in urbaninduced precipitation.

Kruczała (1972) presented interesting conclusions based on an analysis of the spatial distribution of rainfall in the Upper Silesian Industrial District. The author concluded that in the cases where the source of emissions was located in the center of the city, the highest precipitation occurred outside the city's borders, regardless of the wind direction. On the other hand, if the sources of emissions were located on the outskirts of urban agglomeration, the maximum precipitation occurred over the area of the city, regardless of the wind direction.

One of the most polluted cities in Poland, with a high concentration of human-made aerosols serving as cloud condensation nuclei (CCN), is Kraków. Despite the high level of pollution, no significant trend in precipitation totals was observed at four stations in Kraków in the period 1971-2005 (Bokwa 2010). Such results could be a confirmation of the hypothesis put forward by Rosenfeld et. al (2008) that too much aerosol can suppress the precipitation-forming processes.

The impact of urban areas on the distribution of precipitation was verified using the WRF model by Yang et al. (2014). The WRF simulation model was used to investigate the sensitivity of precipitation distribution in and around an urban area to different urban land surface model representations. Analyses of the model suggest that cloud dynamics over the city do not change significantly with urbanization.

The area of Łódź is relatively poorly diversified in terms of geographical features. Its elevation above sea level rises from the south-west to the north-east. The elevation difference is $120.5 \mathrm{~m}$. The urban development of Łódź is fairly compact and not too high. Only 20 buildings in the city exceed 
50 meters in height. The tallest building in the city reaches a height of 78 meters. Larger water reservoirs are located ca. $50 \mathrm{~km}$ from the center of Łódź. Theoretically, an increase in the supply of summer storm cells reaching the area of Łódź with water vapor may happen during their movement over the Jeziorsko reservoir (west of Łódź) or the Sulejowski reservoir (south-east of Łódź). Although the possibility exists of local factors affecting the amount and spatial distribution of extreme precipitation, atmospheric circulation was found to be the most important factor. The impact of large scale spatial factors on anomalous precipitation is confirmed by the observations made by Kosssowska-Cezak and Mrugała (1999). The aforementioned authors obtained a significant temporal coincidence of anomalous precipitation between stations in Warsaw and Lublin. This coincidence in time indicates that the atmospheric processes affecting the amount of precipitation occur at a large spatial scale.

The main objective of the study is to determine the conditions of circulation which favor high precipitation totals in Łódź, as well as the moisture characteristics of the air masses flowing to the area of Poland. An equally important objective is to identify the source areas of the air masses which reached central Poland and contributed to the occurrence of extreme precipitation in Łódź. The existence of significant relationships between atmospheric circulation and transport of water vapor and precipitation is evidenced by the results obtained by, e.g., Veres and $\mathrm{Hu}$ (2013). According to these authors, moisture transport and convergence by the Great Plains low-level jet play a particularly important role in shaping the conditions of summer precipitation in the Central United States. The following sub-goals of the study were considered vital: to verify to what extent the moisture characteristics of the air masses changed before reaching Central Poland, to determine what the spatial distribution of atmospheric pressure was, to locate the areas of convergence of water vapor fluxes, and to verify the existence of areas with increased values of precipitable water over Poland and its close neighborhood.

\section{Data and methods}

For a more in-depth analysis of the conditions affecting high precipitation, six cases were chosen. These cases were distinguished based on the highest 6-hour precipitation totals in the period 2011-2013. The precipitation data originated from 17 measurement sites located in the area of the city of Łódź (Fig. 1). The aforementioned sites are part of the measurement network of the Łódzka Spółka

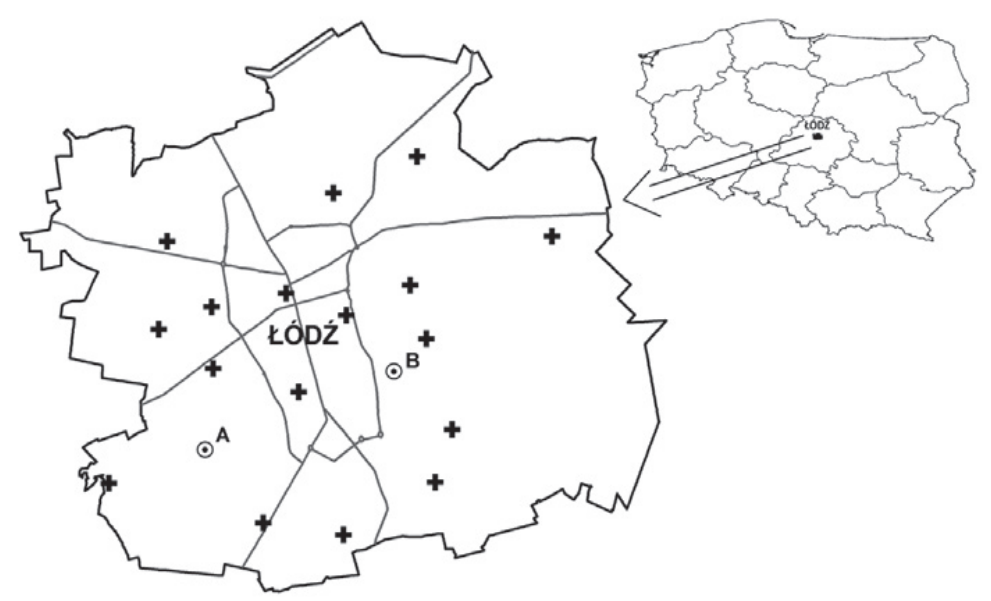

Figure 1. Distribution of measurement sites in Łódź 
Infrastrukturalna (Łódź Infrastructure Company). Precipitation was recorded every $5 \mathrm{~min}$ with an accuracy of $0.1 \mathrm{~mm}$ at a height of $1 \mathrm{~m}$. To record the measurements, TPG-127- $\mathrm{H} 230$ automatic rain gauges having tipping buckets with a volume of $0.1 \mathrm{~mm}$ and a collection area of $200 \mathrm{~cm}^{2}$ were used. Each pluviometer was equipped with a GPRS system transmitting the data to the server. Each transmitter had its own logger, so that data could be recorded even when the signal was lost. The precipitation data for all 17 measurement sites were reviewed in the selected cases when extreme precipitation occurred. Based on one-hour and half-hour precipitation totals, three reference measurement sites were selected where precipitation patterns in the analyzed three-year period were concurrent with each other. During the selected situations of extreme precipitation, the concurrence of one-hour and halfhour precipitation totals from the remaining 15 measurement sites were verified against the reference sites. Furthermore, it was examined whether differences in precipitation total recorded every 5 minutes in the cases with extreme precipitation were not too great. At one of the measurement sites there were gaps in the data and therefore the site was not included in the study. Precipitation data from a longer period of time (1971-2000) were also used in the research. These data came from the weather station Łódź-Lublinek located in the south-western part of Łódź (point $A$, Fig. 1). The data were collected by the Institute of Meteorology and Water Management (IMGW). Daily precipitation records from May to August were used to determine the probability of the occurrence of precipitation equal to or exceeding $10 \mathrm{~mm}$.

The atmospheric circulation conditions were determined following Jenkinson and Collison (1977). The methodology of determining the types of atmospheric circulation is based on the $925 \mathrm{hPa}$ isobaric surface altitude data from 32 points forming a grid of points. The grid of 32 points is positioned so that its central point is located in Łódź (point B), and individual points are spaced apart by about $2.5^{\circ}$ latitude and longitude. The coordinates of the
B point are $51^{\circ} 45^{\prime} \mathrm{N}, 19^{\circ} 30^{\prime} \mathrm{E}$. An example of distribution of grid points with a description of methodology to determine the types of atmospheric circulation can be found in the studies by Piotrowski (2009) and Piotrowski and Jędruszkiewicz (2012). The data on the $925 \mathrm{hPa}$ isobaric surface altitude were taken from the NCEP Reanalysis I dataset (Kalnay et al. 1996). The same database was used to determine moisture conditions over Europe. Moisture conditions over Europe were analyzed based on precipitable water, specific humidity and potential evapotranspiration rate.

In order to determine the direction from which the greatest amount of water vapor came over Poland and how this amount changed during transport, water vapor fluxes at $925 \mathrm{hPa}$ pressure level were calculated based on a formula by Phillips and McGregor (2001). The formula is as follows:

$$
\begin{gathered}
Z_{p}=\frac{q u}{g} \\
M_{p}=\frac{q v}{g} \\
V_{p}=\sqrt{Z_{p}^{2}+M_{p}^{2}}
\end{gathered}
$$

where:

$Z_{p}, M_{p}, V_{p}$ - are zonal, meridional and vector

vapor fluxes, respectively;

$g$ - is acceleration due to gravity;

$q$ - is specific humidity;

$u, v$ - zonal and meridional components of vector wind.

The units of zonal, meridional and vector vapor fluxes are kilograms per meter per Pascal per second.

In order to determine the origin of air masses coming to Łódź based on the six selected cases, the HYSPLIT model (Draxler \& Rolph 2012) was used. The model settings: data sets: GDAS - 0.5 degrees; vertical motion - isobaric; trajectory direction: backward (96 hours); start latitude - 51.75, longitude - 19.5; level: 1000 m AGL. In addition, air temperature, relative humidity (for the calculation of water vapor pressure) and precipitation data along the backward trajectory were used. 


\section{Results and Discussion}

The mean daily precipitation in summer (June-August) in central Poland is ca $2.5 \mathrm{~mm} /$ day, whereas the probability of summer daily precipitation is about 42\% (Groisman et al. 1999). The highest precipitation are recorded in the summer. The highest daily precipitation in the area of Łódź was recorded at the station Łódź-Widzew - 128.6 mm (Kłysik \& Fortuniak 1993). At the station Łódź-Lublinek, there were 22 cases of short wet spells with totals exceeding $50 \mathrm{~mm}$ in the period 1931-1995 (Wibig \& Fortuniak 1998). Most of them occurred in July. In this study tested the probability of precipitation equal to or exceeding $10 \mathrm{~mm}$ depending on the atmospheric circulation type. The highest probability of daily precipitation totals $\geq 10 \mathrm{~mm}$ for the period 1971-2000 was found also in July (9.6\%).

The six cases with the highest six-hour rainfall, selected for the analysis, were recorded in the months between May and August. In all six cases, the six-hour rainfall totals exceeded $18 \mathrm{~mm}$. The probability of daily precipitation $\geq 10 \mathrm{~mm}$ during this period significantly changes not only in individual months but also depending on the advection direction (Fig. 2). The greatest probability of the occurrence of high precipitation ( $\geq 10 \mathrm{~mm}$ ) is, predictably, bigger during cyclonic circulation than during anticyclonic circulation. The probability of the occurrence of high precipitation $\geq 10 \mathrm{~mm}$ during cyclonic circulation for individual months from May to August is 3.1\%, 5.3\%, 5.3\%, $2.3 \%$, respectively, while in the case of anticyclonic circulation it is $0.8 \%, 0.8 \%, 3.4 \%, 1.7 \%$.

A number of scientific studies present the hypothesis that the urban core, as well as the downwind periphery, are two regions especially susceptible to urban-enhanced thunderstorms (Niyogi et al. 2006; Shem \& Shepherd 2009). Thielen et al. (2000) came to similar conclusions, stating that the occurrence of $\mathrm{UHI}$ in the warm season during weak synoptic situations forcing augments convective activity close to the urban core. In the chosen 6 cases, certain spatial regularities in the distribution of precipitation can also be found. In all the cases analyzed (except 7 Aug 2011), was found the highest amount of rainfall in the study area in the part of the city lying more
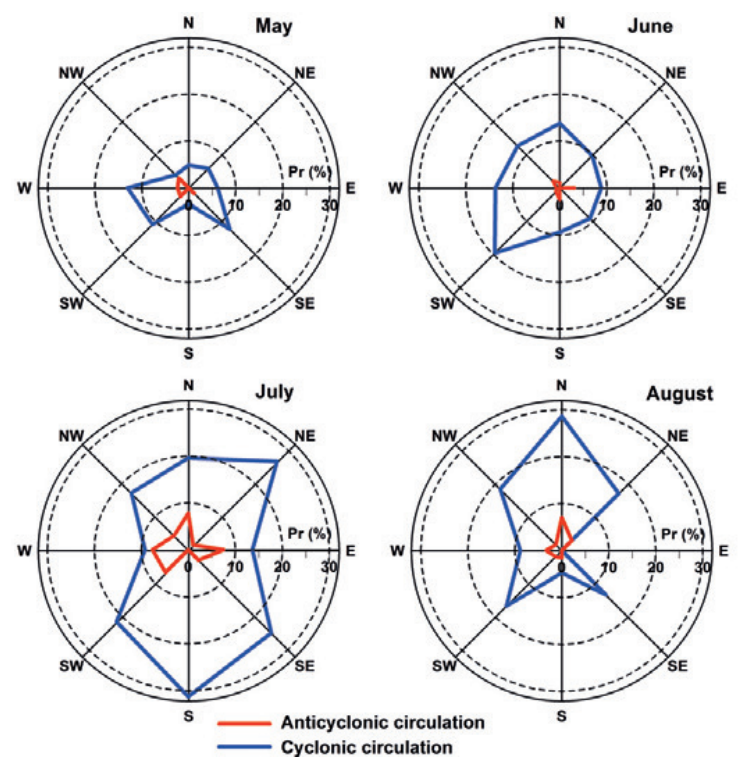

Figure 2. Conditional probability of daily precipitation $\geq 10 \mathrm{~mm}$ at Łódź-Lublinek station in relation to atmospheric circulation 
or less opposite the direction of advection (Fig. 3). This could obviously be a coincidence and a climatic analysis based on a greater number of cases should be done to confirm whether the city actually impacts the rainfall distribution and how often the highest rainfall occurs in the part of the city opposite the direction of advection.

High precipitation in all the cases studied was determined more by global than local factors. This is evidenced by the synoptic situations which then prevailed over the central part of Europe. Each of the six selected precipitation events was shaped by a slightly different synoptic situation. The most similar synoptic conditions prevailed on 27 May, 2013 and 20 July, 2011, when the center of a low pressure system area occurred over Poland (Fig. 4). Heavy precipitation was mainly associated with the occurrence of Cumulonimbus clouds. Cumulonimbus clouds appeared in all the cases studied. They were probably also built into the warm front cloudiness of 20 July 2011. On that day, a low pressure

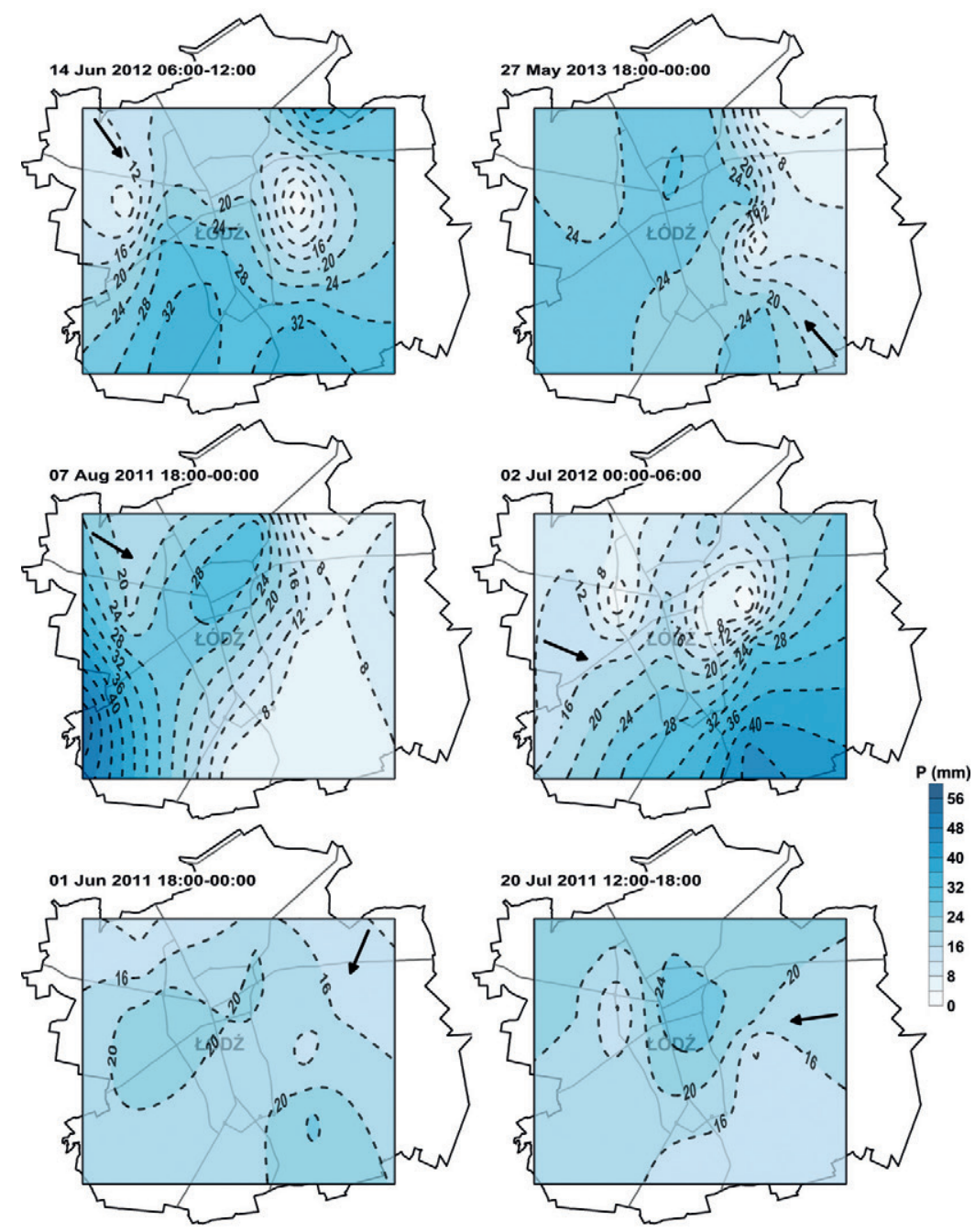

Figure 3. 6-hour precipitation totals in the area of Łódź and advection direction at the elevation of $925 \mathrm{hPa}$ isobaric surface (black arrows) 
system centre was located over the southern part of Poland and warm air was flowing from the south. A similar synoptic situation took place on 27 May 2013; however, a low pressure system centre was this time located close to the center of Poland. A short and intense rainfall of $5 \mathrm{~mm} / \mathrm{min}$ was then observed, which suggests the appearance of Cumulonimbus clouds. The lack of data on the cloud cover just before the onset of precipitation makes it impossible to confirm this fact. Typical convective clouds with high rainfall over
Łódź occurred on 2 July 2012. The cloudiness system that day was associated with a cold front, separating polar air masses from subtropical air. Contact of thermally contrasting air masses also took place on 17 August 2011. On that day, cold air masses from the Atlantic came over Poland displacing warm air masses which had been flowing from the south. The high rainfall of 20 July 2011 was in turn associated with the advection of warm, moist and very unstable tropical air masses from the Mediterranean, which clashed along the

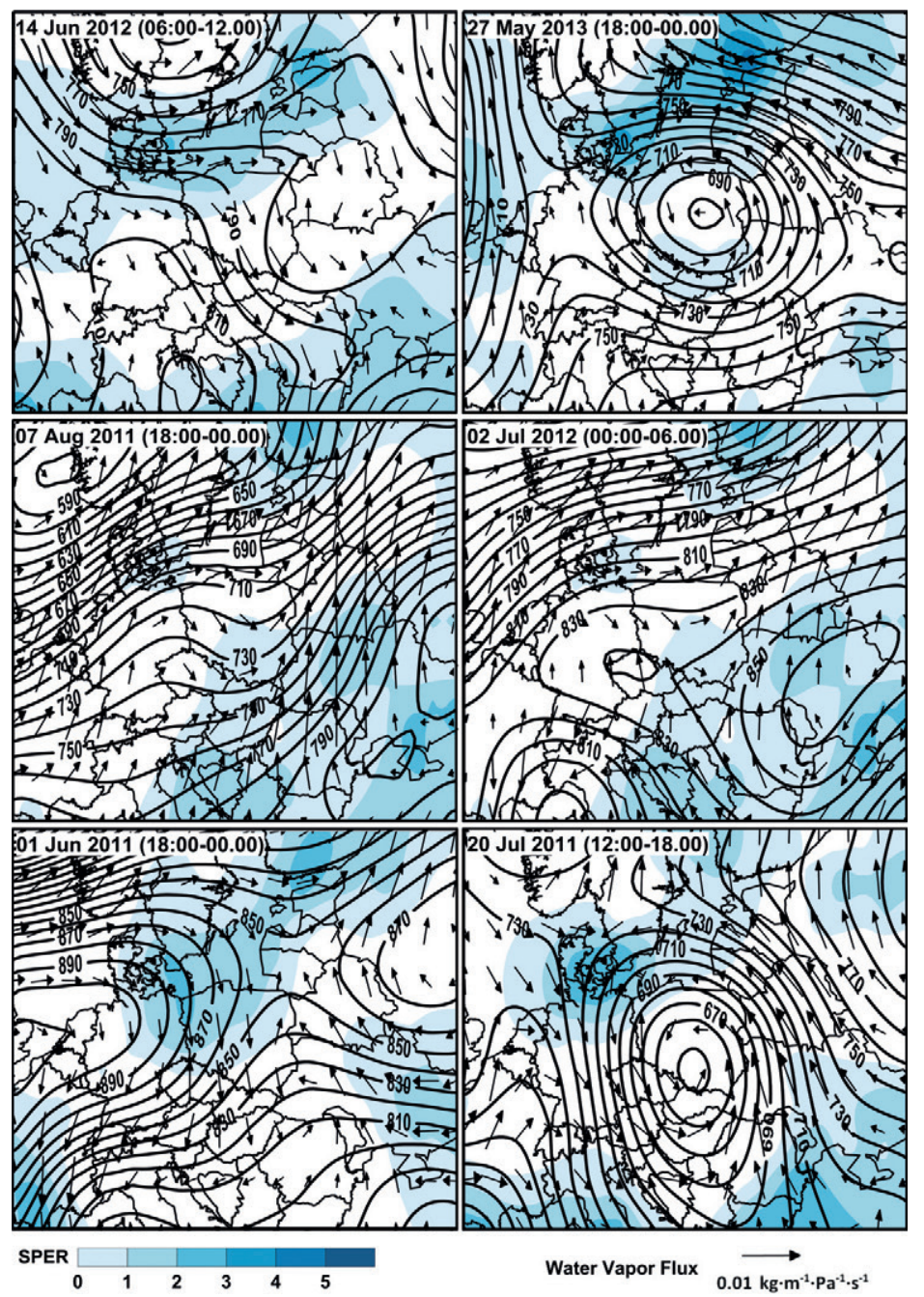

Figure 4. 6-hourly mean values of the elevation of 925hPa isobaric surface, water vapor fluxes and positive standardized deviation of evapotranspiration rate (SPER) 
warm front with cooler masses from the northwest. On 14 June 2012, a supercell was observed over the area of Poland. Between 6:00 am and 12:00 pm the highest rainfall of all the cases studied was observed in Łódź. The rainfall reached $21.2 \mathrm{~mm}$ and even $36.8 \mathrm{~mm}$ in some places. Precipitation in all the cases included in the study was associated with weather fronts moving over the area of Poland. The results confirm previous findings of Łupikasza (2010) that the most extreme precipitation in summer is connected with fronts (65\%).
The cases from 8 August 2011 and 2 July 2012 (Figs. 5c and 5d) had the most similar backward trajectories. The beginnings of the trajectories were for the aforementioned cases quite different and were located in two different water areas - the Atlantic Ocean and the Mediterranean Sea. This was reflected in the initial water vapor content in the air, which is larger in the Mediterranean. However, starting from the center of France there was a gradual decrease in water vapor content on the way to Central Europe. The backward

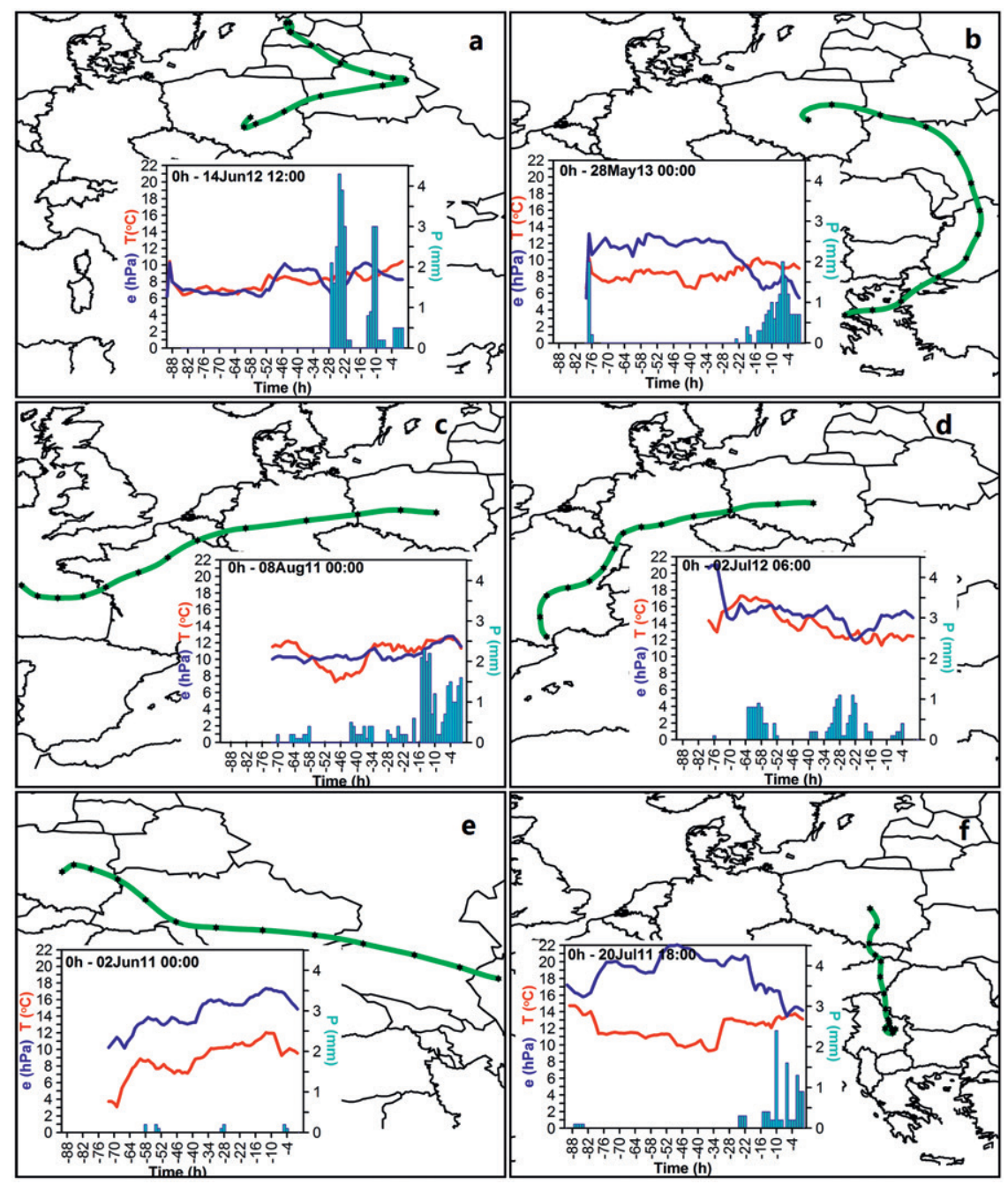

Figure 5. Backward trajectories with plots of air temperature, water vapor pressure and precipitation along backward trajectories. Black dots along trajectory show six-hour time interval 
trajectories of 28 May 2013 and 20 July 2011 (Figs. $5 \mathrm{~b}$ and $5 \mathrm{f}$ ) were different, but the source region of the air masses was located in a close area. The former trajectory was longer and the air mass moved fairly fast without showing greater fluctuations in water vapor pressure. The trajectory of 20 July 2011 was very short. In this case, the stagnation of the air masses at the foot of the Western Carpathians for a considerably long time caused a gradual loss of water vapor. Farther on the trajectory, water vapor content in the air increased. The largest increase in water vapor was noted during the movement of air masses from the source area in the Caspian Sea region (an average of $0.08 \mathrm{hPa} / \mathrm{h}$ ) (Fig. $5 \mathrm{e}$ ). In this case, a particularly significant increase in water vapor was visible over the areas of southeastern Europe. The increase of water vapor fluxes was associated with high evapotranspiration and small losses of water vapor due to very low precipitation totals along the entire trajectory. The backward trajectory for the case of 2 June 2011 also stands out for small precipitation during the migration of air masses into Poland. Quite a significant increase in water vapor content along the backward trajectory was observed during the inflow of air masses from higher latitudes on 14 June 2012. In four cases (Figs. 5a, 5b, 5c and 5d), higher precipitation during the movement of air masses appeared at the end of the journey to the destination point and caused only small variations in water vapor content in the air. The trajectories in all analyzed cases are different, but sometimes, for the short distances are similar. The similar results were obtained by Jędruszkiewicz \& Zieliński (2016) for the period 2010-2013. They analyzed the frequency of 72-hour backward trajectories during the days with precipitation totals $\geq 10 \mathrm{~mm}$ and showed that the backward trajectories were different in particular cases, but the advection of air masses from southwestern Europe was the most frequent.

The analysis of backward trajectories shows that every high precipitation event reduces water content in the atmosphere. Precipitation results in a loss of water in the atmosphere; on the other hand, it increases soil moisture, which contributes to increasing water vapor content in the air through evaporation.

In all the six cases of extreme precipitation, areas with high water content in the atmosphere near the borders of Poland or within its territory are visible (Fig. 6). The areas with the highest values of precipitable water are in 4 cases located in the north eastern part of Poland, while in the other two cases on the Baltic Sea and the Lublin Upland. The higher amount of water vapor in a column of atmosphere over Central Europe during extreme precipitation was also shown by Bernas $\&$ Kolendowicz (2013). The existence of current convergence zones (Fig. 4) over the area of Poland and its close neighborhood contributes to an increase in water content in the atmosphere, since the clash occurs not only between thermally contrasting air masses, but sometimes also between water vapor fluxes.

\section{Summary}

High precipitation occurred in Łódź during various synoptic situations and with different trajectories of air mass inflow. Based on the analysis of data from the years 1971-2000, it has been found that the highest precipitation events in Łódź in the months from May to August appear most frequently during the clash of warm air masses from the south with cooler air masses from the north.

In most of the cases, higher precipitation was observed in the part of the city lying opposite the direction of advection. Due to the convective nature of rainfall, this spatial distribution of rainfall may be only a coincidence, so in order to draw conclusions about the possible impact of the city on precipitation, an analysis based on a longer rainfall data series is necessary.

During extreme precipitation in Łódź, areas of huge concentrations of water in the air column occur near the territory of Poland or within its area. Such sites overlap with the areas reached by warm air masses inflow with a high content of water vapor in the air and where marine air masses flowing from the 
Atlantic clash with marine air masses from the south and south-east. The convergence of air flows is visible in the areas of high concentration of water vapor in the atmosphere or in their neighborhood. The stabilization of this type of synoptic situation for a long time can lead to an increase of water concentration in the atmosphere. In addition, it is conducive to the development of the cyclogenesis process. It is very dangerous, because not only does it contribute to high precipitation totals, but also to their accumulation, and this in turn can lead to local flooding within the city, and at a greater spatial scale to floods.

A review of the selected situations raises a number of questions, notably about the impact of precipitation and evapotranspiration on the increase in water vapor content in the air and the role of water vapor in the formation of precipitation. A synoptic analysis of the selected cases indicates that the formation of $\mathrm{Cu}$ mulonimbus clouds, which produces heavy precipitation, is conducive to a clash of thermally contrasting air masses. This factor appears

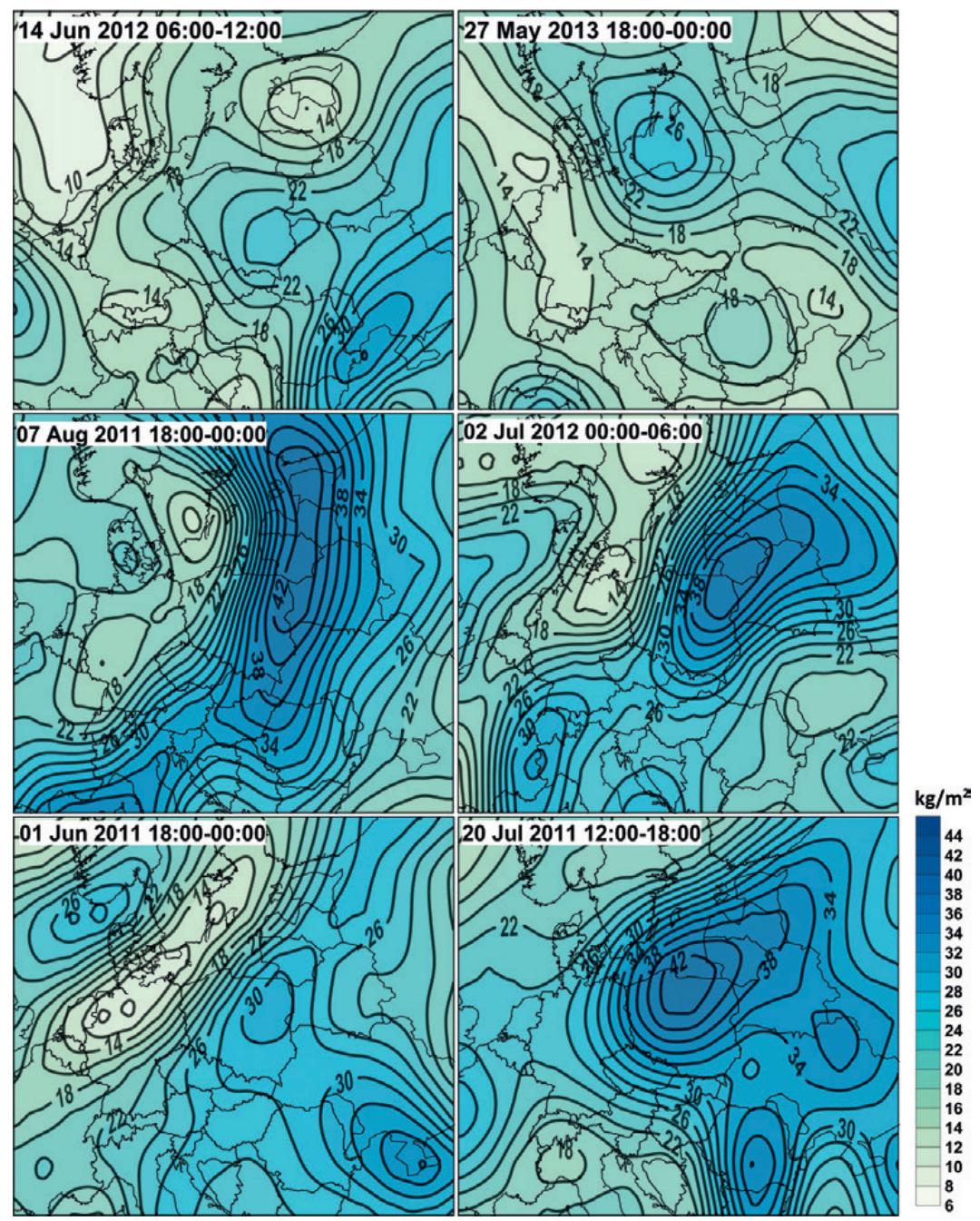

Figure 6. Spatial distribution of 6-hourly mean of precipitable water 
to be the most important in the formation of extreme rainfall in the selected cases. An additional factor contributing to an increase in atmospheric water concentrations and creating favorable conditions for the development of clouds and precipitation is the inflow of air masses carrying large amounts of water vapor from marine areas and from areas with high evapotranspiration. The role of water vapor appears to be less important. Air masses flowing from lower latitudes during the warm half-year are often characterized not only by high humidity, but also by instability resulting in the occurrence of convective clouds, even during cloudiness associated with a warm front.

The assessment of the impact of moisture conditions on the total precipitation in urban areas is only an attempt to verify the role of global circulation in the transport of water

\section{References}

Ackermann B., Changnon S.A., Dzursin G., Gatz, D.L., Grosh R.C., Hilberg S.D., Huff F.A., Mansell J.W., Ochs H.T., Peden M.E., Schickedanz P.T., Semonin R.G., VogelJ.L., 1978. Summary of METROMEX, vol. 2: Causes of precipitation anomalies. Illinois State Water Survey, 63, Urbana: Department of Registration and Education.

Bartnik A., Marcinkowski M., 2015. Przestrzenne zróżnicowanie opadów atmosferycznych na obszarze Łodzi. Acta Universitatis Lodziensis. Folia Geographica Physica, 14, pp. 5-15.

Bernas M., Kolendowicz L., 2013. Wpływ cyrkulacji atmosferycznej na występowanie ekstremalnych opadów atmosferycznych $w$ Poznaniu w latach 1920-2010. Badania Fizjograficzne. Seria A - Geografia Fizyczna, 4 (A63), pp. 7-28.

BokwA A., 2010. Effects of air pollution on precipitation in Kraków (Cracow), Poland in the years 1971-2005. Theoretical and Applied Climatology, vol. 101, nos. 3-4, pp. 289-302.

Dixon P.G., Mote T.L., 2003. Patterns and causes of Atlanta's heat island-initiated precipitation. Journal of Applied Meteorology, vol. 42, no. 9, pp. 1273-1284. vapor over the area of central Poland in conjunction with the amount and distribution of precipitation. To ensure the applicability of the conclusions drawn also to other cases or most of them, it is necessary to perform a further climatic analysis and research including local factors which may affect precipitation totals and their spatial distribution.

\section{Acknowledgements}

The work presented in this paper was supported by Polish National Science Centre under grant 2012/05/B/ST10/00945.

Editors' note:

Unless otherwise stated, the sources of tables and figures are the authors', on the basis of their own research.

DraXler R.R., Rolph G.D., 2012. HYSPLIT HYbrid Single-Particle Lagrangian Integrated Trajectory Model access via NOAA ARL READY. NOAA Air Resources Laboratory, College Park, MD, http:// www.arl.noaa.gov/HYSPLIT.php [26 March 2015].

Dubaniewicz H., 1974. Klimat województwa tódzkiego. Acta Geographica Lodziensia, 34, ŁódźWrocław: Zakład Narodowy im. Ossolińskich.

Groisman P.Y., Karl T.R., Easterling D.R., Knight R.W., Jamason P.F., Hennessy K.J., SupPiah R., PAge CH.M., Wibig J., Fortuniak K., Razuvaev V., Douglas A., Rorland E., Zhal P.M., 1999. Changes in probability of heavy precipitation: Important indicators of climatic change. Climatic Change, vol. 42, no. 1, pp. 243-283.

HaN J.Y., BAIK J.J., LeE H., 2014. Urban impacts on precipitation. Asia-Pacific Journal of Atmospheric Sciences, vol. 50, no. 1, pp. 17-30.

Jenkinson A.F., Coluıson P., 1977. An initial climatology of gales over the North Sea. Synoptic Climatology Branch Memorandum, no. 62, Bracknell: Meteorological Office.

JęDRUSZKIEWICZ J., ZIELIŃSKI M., 2016. Zróżnicowanie wysokich dobowych sum opadów w Łodzi i okolicach na tle cyrkulacji atmosferyczne [in:] Klimat 
i bioklimat miast, Acta Geographica Lodziensia, 104, Łódź: Łódzkie Towarzystwo Naukowe, pp. 201-211.

Kalnay E., Kanamitsu M., Kistler R., Collins W., Deaven D., Gandin L., Iredell M., Saha S., White G., Woollen J., Zhu Y., LeetmaA A., Reynolds B., Chelliah M., Ebisuzaki W., Higgins W., Janowiak J., Mo K.C., RopeleWSKI C., Wang J., JenNe R.L., JosepH D., 1996. The NCEP/NCAR 40-year reanalysis project. Bulletin of the American Meteorological Society, 77, pp. 437-471.

KŁYSIK K., Fortuniak K., 1993. Spatial differentiation of the maximal daily and monthly precipitation in the area of central Poland [in:] B. Sevruk, M. Lapin, A. Becker (eds.), Proceedings of the International Symposium on Precipitation and Evaporation, Bratislava, 1993, Bratislava: Slovak Hydrometeorological Institute, pp. 219-220.

Kotowski A., Kaźmierczak B., Dancewicz A., 2010a. Modelowanie opadów do wymiarowania kanalizacji. Warszawa: Komitet Inżynierii Lądowej i Wodnej PAN.

Kotowski A., Dancewicz A., Kaźmierczak B., 2010b. Czasowo-przestrzenne zróżnicowanie opadów atmosferycznych we Wrocławiu. Ochrona Środowiska, vol. 32, no. 4, pp. 37-46.

Kossowska-Cezak U., Mrugata S., 1999. Opady atmosferyczne o anomalnej wysokości (na przykładzie Warszawy i Lublina). Przegląd Geofizyczny, vol. 44, nos. 1-2, pp. 39-51.

KRUCZAłA K., 1972. Opady atmosferyczne na obszarze Górnośląskiego Okręgu Przemysłowego. Prace i Studia Zakładu Ochrony Regionów Przemysłowych, 12, Wrocław: Zakład im. Ossolińskich.

ŁUPIKASZA E., 2010. Genetyczne typy opadów ekstremalnych w sezonie letnim w Polsce oraz ich zmienność wieloletnia w okresie 1951-2007 [in:] E. Bednorz (ed.), Klimat Polski na tle klimatu Europy. Warunki termiczne i opadowe, Studia i Prace z Geografii i Geologii, 15, Poznań: Bogucki Wydawnictwo Naukowe, pp. 131-145.

Niyogi D, Pielke S.R RA, Adegoke J., Chang H.I., Chase T., Douglas E., Gupte M., Marshall C., Matsui T., Pyle P.C., Shepherd M., 2006. Considering the role of aerosols and land-atmosphere interactions related to agriculture and urbanization in climate studies. American Association of Geographers Annual Meeting, Chicago, March 2006.

PIOTROWSKI P., 2009. Obiektywna metoda klasyfikacji cyrkulacji atmosferycznej dla Polski. Folia Geographica Physica, vol. 10, Łódź: Wydawnictwa Uniwersytetu Łódzkiego.

Piotrowski P., JędruszkieWICZ J., 2012. Projections of thermal conditions for Poland for winters 2021-2050 in relation to atmospheric circulation. Meteorologische Zeitschrift, vol. 22, no. 5, pp. 569-575.

Phillips I.D., Mcgregor G.R., 2001. Western European water vapor flux-southwest England rainfall associations. Journal of Hydrometeorology, vol. 2, no. 5, pp. 505-524.

Rosenfeld D., Lohmann U., Raga G.B., O’Dowd C.D., Kulmala M., Fuzzl S., ReisSell A., Andreae M.O., 2008. Flood or drought: How do aerosols affect precipitation? Science, vol. 321, no. 5894, pp. 1309-1313.

Shem W., Shepherd J.M., 2009. On the impact of urbanization on summertime thunderstorms in Atlanta: Two numerical model case studies. Atmospheric Environment, vol. 92, no. 2, pp. 172-189.

Thielen J., Wobrock W., Gadian A., Mestayer P.G., CREUTIN J.D., 2000. The possible influence of urban surfaces on rainfall development: A sensitivity study in 2D in the mesogamma scale. Atmospheric Research, vol. 54, no. 1, pp. 15-39.

VerES M.C., Hu Q., 2013. AMO-forced regional processes affecting summertime precipitation variations in the central United States. Journal of Climate, vol. 26, no. 1, pp. 276-290.

WIBIG J., FORTUNIAK K., 1998. The extreme precipitation conditions in Łódź in the period 1931-1995. Acta Universitatis Lodziensis. Folia Geographica Physica, 3, pp. 241-249.

Yang Q., Leung L.R., Rauscher S.A., Ringler T.D., TAYLOR M.A., 2014. Atmospheric moisture budget and spatial resolution dependence of precipitation extremes in aquaplanet. Journal of Climate, vol. 27, no. 10, pp. 3565-3581.
(C) Piotr Piotrowski

(C) Geographia Polonica

(C) Institute of Geography and Spatial Organization

Polish Academy of Sciences - Warsaw • 2017
Article first received • December 2015 Article accepted • December 2016 